REVISTA INTERNACIONAL DE CIENCIAS DEL DEPORTE International Journal of Sport Science

Rev. int. cienc. deporte

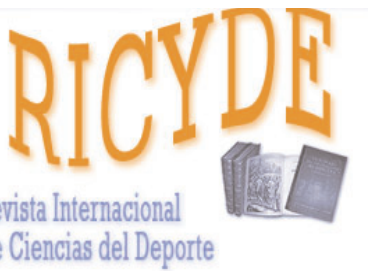

International Journal of Sport Science VOLUMEN X - AÑO X

Páginas:305-318 ISSN:1885-3137

No 38 - Octubre - 2014

http://dx.doi.org/10.5232/ricyde2014.03802

\title{
The effect of holographic wristbands on body balance Efecto de las pulseras holográficas en el equilibrio corporal
}

\author{
Iván Gonzaloํ, Pedro J. Benito ${ }^{1}$, José M. Delfa ${ }^{2}$, Juan C. Miangolarra², Miguel A. Rojo-Tirado ${ }^{1}$
}

1. Facultad de Cencias de la Actividad Física y del Deporte (INEF). Universidad Politécnica de Madrid. Spain

2. Facultad de Ciencias de la Salud. Universidad Rey Juan Carlos. Spain

\begin{abstract}
Balance is a complex ability essential for the performance of any motor task and for preventing injuries and falls. The appearance of holographic wristbands, the supposed benefits of which include improved balance, received the attention of the public and the media alike. However, there is no scientific evidence that holograms improve any physical attribute. The aim of this study was to evaluate the effect of Power Balance $\mathbb{R}$ holographic wristbands on balance. Following a triple-blind method, 25 healthy and physically active university students (14 women, 11 men) underwent the sensory organization test (SOT) on two separate days while wearing a wristband with or without holograms (the tests being performed in a random but counterbalanced order). The SOT provides details on total balance and the relative contribution of the three main sensory systems (somatosensory, vestibular and visual) involved in balance. The results for the group as a whole revealed the wearing of a holographic wristband to have no significant effect on any of these variables. However, when the women's results were analyzed separately, the wearing of holographic wristbands was associated with significant differences in the scores of two SOT variables: composite balance $(86.5 \pm 3.7$ with the holographic wristband compared to $85.5 \pm 4.5$ without it; $\mathrm{p} \leq 0.05)$ and overall mean $(93.5 \pm 2.0$ compared to $92.8 \pm 2.4 ; p \leq 0.05$ ). Although these statistical differences were discovered, the magnitude of these differences was so small that balance could not have been improved in any practical sense. In conclusion, Power

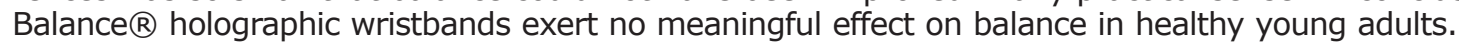

Key words: Power Balance; hologram; SOT test; balance; wristband.

\section{Resumen}

El equilibrio es una habilidad compleja esencial para la realización de cualquier tarea motriz y para la prevención de lesiones y caídas. La aparición de las pulseras holográficas, con supuestos beneficios entre los cuales se incluye la mejora del equilibrio, recibió la atención del público y los medios de comunicación por igual. Sin embargo, no hay evidencia científica de que los hologramas mejoren cualquier atributo físico. El objetivo de este estudio fue evaluar el efecto de las pulseras holográficas Power Balance $\AA$ en el equilibrio. Siguiendo un método triple ciego, 25 estudiantes sanos y físicamente activos universitarios (14 mujeres, 11 hombres) fueron sometidos a la prueba de organización sensorial (SOT) en dos días separados mientras llevaban una pulsera con o sin hologramas (los ensayos se realizaron al azar en un orden contrabalanceado). EI SOT proporciona detalles sobre el equilibrio total y la contribución relativa de los tres sistemas sensoriales principales (somatosensoriales, visuales y vestibulares) que intervienen en el equilibrio. Los resultados para el grupo como un todo revelaron que el uso de una pulsera holográfica no tiene ningún efecto significativo en cualquiera de estas variables. Sin embargo, cuando se analizaron los resultados de las mujeres de forma aislada, el uso de las pulseras holográficas se asoció con diferencias significativas en las puntuaciones de dos variables SOT: Equilibrio compuesto ( $86.5 \pm 3.7$ con la pulsera holográfica en comparación con $85.5 \pm 4.5$ sin ella; $\mathrm{p} \leq 0.05)$ y la media general $(93.5 \pm 2.0$ en comparación con $92.8 \pm 2.4 ; \mathrm{p} \leq 0.05)$. Sin embargo, aunque a nivel estadístico estas diferencias fueron encontradas, la magnitud era tan pequeña que el equilibrio no se podría haber mejorado en ningún sentido práctico. En conclusión, las pulseras holográficas Power Balance $\mathbb{R}$ no ejercen ningún efecto significativo en el equilibrio en adultos jóvenes sanos.

Palabras claves: Power Balance; holograma; test SOT; equilibrio; pulsera.

Correspondence/correspondencia:Iván Gonzálo

Facultad de Ciencias de la Actividad Física y el Deporte (INEF). Universidad Poltécnica de Madrid. Spain.

E-mail: ivan600@gmail.com 
Gonzalo, I.; Benito, P. J.; Delfa, J. M.; Miangolarra, M. A.; Rojo-Tirado, M. A. (2014). The effect of holographic wristbands on body balance. RICYDE. Revista internacional de ciencias del deporte, 38(10), 305-318. http://dx.doi.org/10.5232/ricyde2014.03802

\section{Introduction}

B alance in humans is defined as the ability to maintain one's center of gravity within the base of support, and is usually classified as static or dynamic (DiStefano, Clark, \& Padua, 2009; Tsigilis \& Theodosiou, 2008). Static balance refers to the ability to maintain the center of gravity within the base of support during the absence of movement (Goldie, Bach, \& Evans, 1989), while dynamic balance refers to the same during the transition between standing still and moving when some movement is made (Ross \& Guskiewicz, 2004). Currently, balance is understood to be a complex motor ability that integrates many types of sensory information, as well as the planning and execution of flexible movement patterns, the aim of which is to be able to assume infinity of positions (Horak, 1997; Nashner \& Peters, 1990).

The functional aims of the balance system include: 1) the maintenance of a specific postural alignment (such as sitting or walking); 2) to facilitate voluntary movement and the transition between postures, and 3) to permit reactions allowing the recovery of balance in the face of external stimuli (such as slipping or stumbling) (Mancini \& Horak, 2010). Good posture control is attained via the complex integration and coordination of multiple systems. The premotor sensory systems include the vestibular, visual, auditory and somatosensory pathways. Sensory information is interpreted within the central nervous system, which formulates a motor response. Different muscular synergies are then activated to coordinate the appropriate movement of trunk, head, eyes, arms and legs in order to maintain or attain the desired posture (Day, Guerraz, \& Cole, 2002; Lephart, Riemann, \& Fu, 2000; Mancini \& Horak, 2010).

Correct balance and posture control, and their recovery when affected by an injury or disease, are important factors in health and performance. Balance deficit increases the risk of suffering knee and ankle injuries (Hrysomallis, 2007; McGuine, Greene, Best, \& Leverson, 2000), of suffering falls in adulthood (Ganz, Bao, Shekelle, \& Rubenstein, 2007; Muir, Berg, Chesworth, Klar, \& Speechley, 2010; Visser, Carpenter, van der Kooij, \& Bloem, 2008), and explains some of the differences between people with and without chronic ankle instability (McKeon \& Hertel, 2008a, 2008b; Wikstrom, Fournier, \& McKeon, 2010). In contrast, having very good balance is associated with greater independence and functionality during the activities of everyday life (Lord \& Sturnieks, 2005; Sturnieks, St George, \& Lord, 2008), the development of the central nervous system in children (Cumberworth, Patel, Rogers, \& Kenyon, 2007; Ferber-Viart, Ionescu, Morlet, Froehlich, \& Dubreuil, 2007), fewer leg injuries (Valovich McLeod, 2008) and better sporting performance (Gautier, Thouvarecq, \& Vuillerme, 2008; Sell, Tsai, Smoliga, Myers, \& Lephart, 2007).

In subjects free of neuronal, vestibular or visual disease, balance training involves different exercise programs designed to improve sensomotory and neuromuscular skills (Hübscher, Zech, Pfeifer, Hánsel, Vogt, \& Banzer, 2010). These programs involve different movement patterns -combinations of static and dynamic exercises- performed on stable, unstable and irregular surfaces, and a wide range of stimuli (DiStefano et al., 2009; Heitkamp, Horstmann, Mayer, Weller, \& Dickhuth, 2001; Hrysomallis, 2007; Sparkes \& Behm, 2010).

Holographic wristbands made from a simple strip of silicon or neoprene carrying two identical holograms recently appeared on the market. Their manufacturers claim they increase the wearer's strength, flexibility and above all balance (Galván, 2010). A hologram is a three-dimensional image recorded microscopically using a laser directed onto a photosensitive film (made of a polymer, a hydrogel, a gelatin, elastomere or thermoplastic. etc.) (Gabor, Kock, \& Stroke, 1971; Martín Pascual, 1997). In the field of health, holography 
Gonzalo, I.; Benito, P. J.; Delfa, J. M.; Miangolarra, M. A.; Rojo-Tirado, M. A. (2014). The effect of holographic wristbands on body balance. RICYDE. Revista internacional de ciencias del deporte, 38(10), 305-318. http://dx.doi.org/10.5232/ricyde2014.03802

is mainly used in three-dimensional imaging systems for the recording of information (Metha, 2005; Shiota, 2008), or in the production of biosensors that indicate via chromatic changes the concentration of metabolites such as lactate (Sartain, Yang, \& Lowe, 2006) or glucose (Kabilan, Marshall, Sartain, Lee, Hussain, \& Yang, 2005), or the pH (Marshall, Blyth, Davidson, \& Lowe, 2003). To our knowledge, we could only find four studies that was performed to determine de effectiveness or the holographic balance band with regard to improved balance, flexbility, and strength (Verdan, Marzilli, Barna, Roquemore, Fenter, Blujus, \& Gosselin, 2012; Teruya, Matareli, \& Romano, 2013; Brice, Jarosz, Ames, Baglin, \& Da Costa, 2011; Pothier, Thiel, Khoo, Dillon, \& Rutka, 2012).

Despite its popularity and many endorsements by profesional athletes, holographic wristbands have not demonstrated and effect on improving dynamic (Teruya, Matareli, \& Romano, 2013) or static balance control (Verdan, Marzilli, Barna, Roquemore, Fenter, Blujus, \& Gosselin, 2012; Pothier, Thiel, Khoo, Dillon, \& Rutka, 2012). The specific test was used as a determinant of balance was the modified Test of Sensory Interaction on Balance (m-CTSIB). This test required that the subjects remain in a motionless position under four conditions (eyes open and closed on both firm and compliant surfaces) during 30 seconds trials (Verdan, Marzilli, Barna, Roquemore, Fenter, Blujus, \& Gosselin, 2012; Pothier, Thiel, Khoo, Dillon, \& Rutka, 2012). The Sensory Organization Test (SOT) utilizes dynamic posturography (standing on forcé plate) to objectively measure postural sway and center of pressure (COP) under the same testing conditiongas the m-CTSIB, but with 20 seconds trials, with feet shoulder width apart and with two more conditions, with the visual reference and the force plate in movement (Leitner, Mair, Paul, Wick, Mittermaier, Sycha, 2009). The six conditions measures during SOT allow differentiationg the relative importance of each of the components of the balance.

Given the worldwide commercial and media interest associated with these wristbands (Galván, 2010; Pérez-Lanzac, 2010), but the lack of evidence that they are able to provide any of their claimed benefits, the aim of the present work was to determine whether Power Balance ${ }^{\circledR}$ holographic wristbands have any positive effect on one of the main components of human balance of healthy young adults.

\section{Methods}

\section{Preliminary systematic review}

A preliminary systematic review of the literature was performed following the recommendations of Peinado (Peinado, Molina, Montero, Lozano, Caro, Sánchez, \& Tejero, 2007), adapting them to the procedures followed in other systematic reviews on balance and physical activity (DiStefano, Clark, \& Padua, 2009; Hübscher, Zech, Pfeifer, Hänsel, Vogt, \& Banzer, 2010). Electronic searches were made of the PubMed, Cochrane Plus, ISI Web of Knowledge $^{\mathrm{SM}}$ and SPORTDiscus databases, using different combinations of the terms: "postural stability or control or balance or sway", "balance or equilibrium or proprioception or stability or strength or flexibility", and "Power Balance ${ }^{\circledR}$ or strap or bracelet or wristband". Searches were made between January 11990 and February 282014 for papers written in English or Spanish. No study relating such wristbands to physical activity or balance was found.

\section{Experimental design}

The present work had a triple blind (subjects, researcher, statistician), cross-over design (i.e., in which subjects become their own controls), and in which the independent variable was the 
Gonzalo, I.; Benito, P. J.; Delfa, J. M.; Miangolarra, M. A.; Rojo-Tirado, M. A. (2014). The effect of holographic wristbands on body balance. RICYDE. Revista internacional de ciencias del deporte, 38(10), 305-318. http://dx.doi.org/10.5232/ricyde2014.03802

wearing of a wristband with or without holograms. The tests the subjects underwent (see below) were performed in a random and counterbalanced order.

\section{Subjects}

The study subjects were 25 students of physiotherapy (14 women, 11 men). All subjects were physically active and all had prior experience of the sensory organization test (SOT). In agreement with the Helsinki Declaration regarding the use of human subjects in research (World Medical Association, 2004), all those taking part were informed of the nature of the study and its aims, and all provided signed consent to be included.

The inclusion criteria demanded never having worn a Power Balance ${ }^{\circledR}$ holographic wristband (or similar wristband); never having suffered a lower limb joint sprain requiring immobilization or body weight alleviation during walking for at least three days in the last year; to have no pain, weakness or instability in the lower limbs or neck; to be taking no medication with any possible secondary effect on balance or that might cause drowsiness; to have experienced no dizziness, fainting or loss of balance during the activities of daily life in the last year; to have no diagnosed visual, cervical or vestibular disease; to be able to stand upright for at least 20 min without aid; to have undergone SOT testing at least four times (some authors recommend subjects undergo such testing at least twice to overcome testretest learning effects (Dickin, 2010; Dickin \& Clark, 2007; Grindstaff et al., 2006), it would appear that such learning reaches a plateau during the 3rd-4th repetition of the test (Wrisley, Stephens, Mosley, Wojnowski, Duffy, \& Burkard, 2007); and to have a bodyweight of $18-136 \mathrm{~kg}$ and a height of 76-203 $\mathrm{cm}$ according to the recommendations of the test device manufacturer (NeuroCom ${ }^{\circledR}$ International, 2006).

\section{Materials}

Balance tests were performed using the SMART Equitest ${ }^{\circledR}$ computerized dynamic posturographic system (NeuroCom ${ }^{\circledR}$ International Inc., Clackamas, OR). This apparatus involves a dual force platform $(45.72 \times 45.72 \mathrm{~cm})$ mounted on four extensiometric transducers that measure the vertical forces generated by the subject. The apparatus incorporates a surrounding visual environment system (see Fig. 1). Via the use of three servomotors, the visual reference as well as the platform itself can be moved through $\pm 10^{\circ}$ at a maximum rate of $15 \%$ s for the visual environment and $50 \%$ s for the platform (Leitner, Mair, Paul, Wick, Mittermaier, Sycha, 2009). 


\section{VISUAL CONDITION}

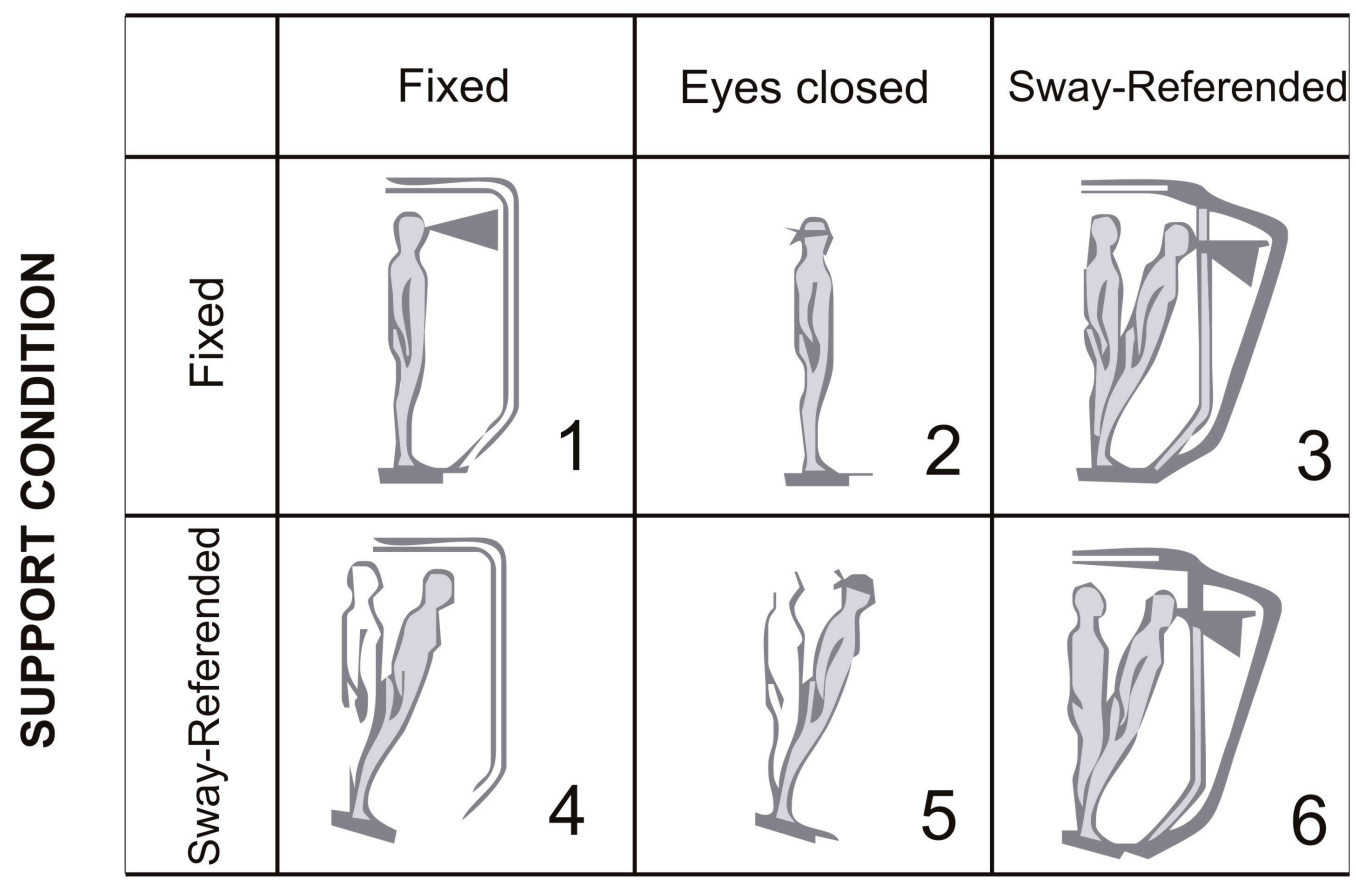

Figure 1. Undertaking the SOT.

When required to do so, subjects wore one of two silicon Power Balance ${ }^{\circledR}$ wristbands of the same color, one with the interwoven holograms covered by opaque tape, the other with these holograms removed in such a way as not to damage the silicon band in any way. These were then covered with opaque tape as above. Each band was coded and a record of the codes and condition of the bands (with or without holograms) made by an invited searcher who took no further part in the experiment.

\section{Protocol}

The subjects were told not to partake in any physical activity, nor to drink any alcohol or take any medication (or any other type of drug) during the experimental period. On two consecutive days they underwent a standardized SOT for the measurement of balance. Tests were performed in a random but counterbalanced order. On each day the subjects wore a wristband with a different code (i.e., either with or without holograms, but unknown to the subject or researchers). The SOT involves a sequence of six sensorial conditions (Fig. 1). Three assays lasting 20s were undertaken under each of these conditions; these are always performed in the order 1-6 (Fig. 1).

The SOT is a dynamic posturography test and is the gold standard method for assessing the motor and sensorial contribution to human balance (Horak, 1997; Mancini \& Horak, 2010). The test was developed with the aim of determining the relative importance of the three main sensorial systems (vestibular, visual and proprioceptive) involved in balance (Nashner \& Peters, 1990). It provides very useful functional information that allows possible deficits to be identified, and affords a good way of monitoring the progress being made by persons receiving therapy or undergoing balance training (Furman, 1994; Mirka \& Black, 1990). The reliability, sensitivity, specificity and validity of the SOT have been confirmed by many authors (Broglio, Ferrara, Sopiarz, \& Kelly, 2008; Cumberworth, Patel, Rogers, \& Kenyon, 2007; Dickin, 2010; Ford-Smith, Wyman, Elswick, Fernandez, \& Newton, 1995; Geldhof, 
Gonzalo, I.; Benito, P. J.; Delfa, J. M.; Miangolarra, M. A.; Rojo-Tirado, M. A. (2014). The effect of holographic wristbands on body balance. RICYDE. Revista internacional de ciencias del deporte, 38(10), 305-318. http://dx.doi.org/10.5232/ricyde2014.03802

Cardon, Bourdeaudhuij, Danneels, Coorevits, \& Vanderstraeten, 2006; Hamid, Hughes, \& Kinney, 1991; Wrisley, Stephens, Mosley, Wojnowski, Duffy, \& Burkard, 2007).

The study subjects stood barefoot on the platform, the malleoli being positioned depending on the height of each, in accordance with the manufacturer's instructions (NeuroCom®International, 2006). During testing, the subjects were never touched.

The sampling frequency selected was $100 \mathrm{~Hz}$; a Butterworth digital filter with a cut-off frequency of $0.85 \mathrm{~Hz}$ was used. A balance reference ratio of 1 was selected. This means that, under the conditions in which the platform or visual environment are moved (conditions 3-6), their position changes with respect to the subject's center of pressure with a maximum delay of $0.34 \mathrm{~ms}$ (Leitner, Mair, Paul, Wick, Mittermaier, Sycha, 2009). This small latency guarantees that the ankle angles and/or visual field remain practically constant with respect to subject postural sway since the neuromuscular system does not react as quickly as the machine (Shepard, Schultz, Alexander, Gu, \& Boismier, 1993).

\section{Data processing}

All posturographic readings were taken automatically and recorded using NeuroCom System Version 8.2 software (NeuroCom ${ }^{\circledR}$ International, Inc, Clackamas, OR). The result (the equilibrium score) obtained under the different conditions is provided as a percentage of the anteroposterior sway of the center of pressure (in degrees) with respect to the theoretical stability limits for a healthy person (in this case with a limit of $12.5^{\circ} ; 8^{\circ}$ forward and $4.5^{\circ}$ backward) (Nashner, 1993; Nashner, Shupert, Horak, \& Black, 1989). The scores for each test were expressed on a scale of 0 (fall) to 100 (perfect stability).

The composite balance was determined as the mean of the scores obtained in tests 1 and 2, plus the scores obtained under conditions 3-6, divided by 14 (NeuroCom ${ }^{\circledR}$ International, 2001). The overall mean is the arithmetic mean for three assays for each of the six tests. Table 1 shows the calculations required to determine the final score for each sensorial system.

Table 1. Sensorial analysis in the SOT

\begin{tabular}{|l|c|l|}
\hline Sensorial system & $\begin{array}{c}\text { Calculation method to } \\
\text { determine the final } \\
\text { scores for from the } \\
\text { equilibrium scores } \\
\text { obtained for each } \\
\text { condition set }\end{array}$ & \multicolumn{1}{|c|}{ Meaning } \\
\hline Somatosensorial & $2 / 1$ & $\begin{array}{l}\text { Importance of somatosensorial system in } \\
\text { balance when visual references are } \\
\text { eliminated }\end{array}$ \\
\hline Visual & $4 / 1$ & $\begin{array}{l}\text { Importance of visual system when } \\
\text { somotasensorial references are } \\
\text { imprecise. }\end{array}$ \\
\hline Vestibular & $5 / 1$ & $\begin{array}{l}\text { Importance of vestibular system when } \\
\text { somotasensorial references are imprecise } \\
\text { and visual references eliminated }\end{array}$ \\
\hline Visual preference & $3+6 / 2+5$ & $\begin{array}{l}\text { Importance of visual preference in the } \\
\text { maintenance of balance }\end{array}$ \\
\hline
\end{tabular}


Gonzalo, I.; Benito, P. J.; Delfa, J. M.; Miangolarra, M. A.; Rojo-Tirado, M. A. (2014). The effect of holographic wristbands on body balance. RICYDE. Revista internacional de ciencias del deporte, 38(10), 305-318. http://dx.doi.org/10.5232/ricyde2014.03802

\section{Statistical analysis}

The means of all studied variables were calculated. Normality was examined using the Kolmogorov-Smirnov test, and by analyzing the asymmetry and kurtosis of the variables. This showed all variables to have a normal distribution, confirming that parametric tests could be used in further analysis. The effect of wearing a wristband with and without the holograms was analyzed using the Student $t$ test for paired samples. The Student $t$ test for independent samples was used to test for any difference in the results due to sex. The Levenne test was used to guarantee the homogeneity of the variances and therefore the comparability of the results of men and women. Significance was set at $p \leq 0.05$. All calculations were performed using SPSS v.15.0 software for Windows (SPSS Worldwide Headquarters, Chicago, IL).

\section{Results}

Table 2 describes the characteristics of the subjects who participated in the study.

Table 2. Characteristics of the study subjects (mean, S.D.).

\begin{tabular}{|l|l|l|l|}
\hline & Men $(\mathbf{n}=11)$ & Women $(\mathbf{n}=14)$ & Total $(\mathbf{n}=\mathbf{2 5})$ \\
\hline Age & $22.81(2.75)$ & $23.42(3.47)$ & $23.11(3.11)$ \\
\hline Weight & $72.27(10.53)$ & $65.72(15.5)$ & $69.99(13.01)$ \\
\hline Height & $177.5(7.09)$ & $166.21\left(3.76^{\mathrm{a}}\right)$ & $171.85(5.42)$ \\
\hline Body mass index & $22.81(1.96)$ & $23.89(6.25)$ & $23.35(4.10)$ \\
\hline $\mathrm{a}=$ Significant difference between sexes at $\mathrm{p} \leq 0.05$. \\
\hline
\end{tabular}

No subject fell during any of the tests. Table 3 shows the raw data for each variable analyzed, for both sexes and for all subjects as a whole.

Table 3. Values recorded for men, women and all subjects (mean, S.D.) wearing wristbands with and without holograms.

\begin{tabular}{|c|c|c|c|}
\hline & Men & Women & All subjects \\
\hline Composite balance "without" & $85.4(1.8)$ & $85.5(4.5)$ & $85.4(3.5)$ \\
\hline Composite balance "with" & $85.1(1.2)$ & $86.5\left(3.7^{\mathrm{a}}\right)$ & $85.9(2.9)$ \\
\hline Somatosensorial "without" & $0.985(0.017)$ & $0.974(0.016)$ & $0.979(0.017)$ \\
\hline Somatosensorial "with" & $0.979(0.015)$ & $0.970(0.030)$ & $0.974(0.025)$ \\
\hline Visual "without" & $0.944(0.034)$ & $0.954(0.022)$ & $0.950(0.028)$ \\
\hline Visual "with" & $0.951(0.024)$ & $0.958(0.027)$ & $0.955(0.025)$ \\
\hline Vestibular "without" & $0.777(0.083)$ & $0.768(0.081)$ & $0.772(0.080)$ \\
\hline Vestibular "with" & $0.745\left(0.072^{c}\right)$ & $0.791(0.065)$ & $0.771(0.071)$ \\
\hline Visual preference "without" & $1.033(0.042)$ & $1.032(0.046)$ & $1.033(0.043)$ \\
\hline Visual preference "with" & $1.046(0.050)$ & $1.030(0.054)$ & $1.037(0.052)$ \\
\hline Overall mean "without" & $92.6(1.6)$ & $92.8(2.4)$ & $92.7(2.0)$ \\
\hline \multirow[t]{2}{*}{ Overall mean "with" } & $90.4(4.6)$ & $93.5\left(2.0^{\mathrm{ab}}\right)$ & $92.2(3.7)$ \\
\hline & $\mathrm{n}=11$ & $\mathrm{n}=14$ & $\mathrm{n}=25$ \\
\hline $\begin{array}{l}\text { "Without" indicates wristband wi } \\
\text { a. Differences detected with respe } \\
{ }^{b} \text {. Difference detected between se } \\
{ }^{c} \text {. Trend towards significance }(\mathrm{p}=0\end{array}$ & $\begin{array}{l}\text { out holograms, "W } \\
\text { to wristband type } \\
(\mathrm{p} \leq 0.05) \text {. } \\
56 \text { ). }\end{array}$ & cates wristband $\mathrm{w}$ & ams. \\
\hline
\end{tabular}


Gonzalo, I.; Benito, P. J.; Delfa, J. M.; Miangolarra, M. A.; Rojo-Tirado, M. A. (2014). The effect of holographic wristbands on body balance. RICYDE. Revista internacional de ciencias del deporte, 38(10), 305-318. http://dx.doi.org/10.5232/ricyde2014.03802

When the results of all the subjects as a whole were analyzed, the wearing of a wristband with holograms was seen to have no effect on any studied variable $(p>0.05)$.

When analyzing the results for women and men separately, the wearing of a wristband with holograms had no effect on any sensorial variable (somatosensorial, visual, vestibular or visual preference). Sex had no effect either $(p>0.05)$.

However, in women, the wearing of a wristband with holograms did have a significant effect on composite balance and the overall mean [ $86.5 \pm 3.7$ 'with' compared to $85.5 \pm 4.5$ 'without' $(\mathrm{p}=0.047)$, and $93.5 \pm 2.0$ 'with' compared to $92.8 \pm 2.4$ 'without' $(\mathrm{p}=0.013)$ ] respectively. In men, no such differences were seen, although the wearing a wristband with holograms had a vestibular effect close to significance.

The wearing of a wristband with holograms also had a significant effect on the overall mean of women compared to men.

\section{Discussion}

The most important finding of this work is that, in young, healthy women, the use of a holographic wristband had a statistically significant effect on composite balance -the most useful variable for assessing balance in this kind of test (Ford-Smith, Wyman, Elswick, Fernandez, \& Newton, 1995). However, the improvement was very small at just $0.44 \pm 1.80$ points, a figure much smaller than the minimum proposed by other authors as that required for there to be any significant effect on balance; one must not confuse a statistical difference at the mathematical level with a real effect at subject level. For example, Broglio (Broglio, Ferrara, Sopiarz, \& Kelly, 2008) indicate a difference of 6.02 in the composite balance score (with a confidence of 70\%) to be necessary for any improvement in balance to be real, a figure much higher than that recorded in the present work. Other authors have established a minimum 5\% increase in the score as the threshold indicating that an improved SOT score is not a reflection of familiarization with the test (Grindstaff, Christiano, Broos, Straub, Darr, \& Westphal, 2006). The counterbalanced, randomized design of the present study, as well as the prior experience of the subjects with the SOT, ought to largely prevent the influence of any learning effect on the SOT results. In any event, when the 5\% figure suggested by Grindstaff (Grindstaff, Christiano, Broos, Straub, Darr, \& Westphal, 2006) is taken into account, a further increase of at least four points would be required for it to be claimed that the holographic wristbands had been responsible for any important gain in postural control. Indeed, some authors suggest even greater differences must be seen. Wrisley (Wrisley, Stephens, Mosley, Wojnowski, Duffy, \& Burkard, 2007) indicate that in young healthy young adults an improvement of 8 points in composite balance is necessary before any significant improvement is seen beyond that of adaptation to the SOT.

Other training media have been shown to have an effect on the SOT result. In a study involving 11 elderly men, a change in the composite balance score of $7.8 \pm 6.9 \%$ was recorded after training with progressive loads over a period of 20 weeks (two training sessions per week) (Galvao, Nosaka, Taaffe, Spry, Kristjanson, \& McGuigan, 2006). Other authors indicate that global vibration stimulus induced using a vibrating platform (semi-squat position, amplitude $3 \mathrm{~mm}$, maximum tolerable frequency, five series of 1 min with a $1 \mathrm{~min}$ rest between series) induces significant changes in composite balance within 15 min compared to a control group receiving placebo treatment (same position, stimulation by transcutaneous electrical nerve stimulation) (Schuhfried, Mittermaier, Jovanovic, Pieber, \& Paternostro-Sluga, 2005). However, it is difficult to compare the results of the latter two 
Gonzalo, I.; Benito, P. J.; Delfa, J. M.; Miangolarra, M. A.; Rojo-Tirado, M. A. (2014). The effect of holographic wristbands on body balance. RICYDE. Revista internacional de ciencias del deporte, 38(10), 305-318. http://dx.doi.org/10.5232/ricyde2014.03802

studies with those of the present work given the difference in the age of the subjects and their health status.

One of the reasons why the holographic wristbands had no effect on the majority of variables measured may lie in the present subjects' high initial balance scores, which leave little room for improvement (Grindstaff, Christiano, Broos, Straub, Darr, \& Westphal, 2006). Certainly, none of the subjects suffered a fall. This indicates that none of the subjects suffered any notable dysfunction of the postural control system. A possible lack of room for improvement has also been reported by other authors whose subjects were of similar age to those of the present study (Cohen, Heaton, Congdon, \& Jenkins, 1996; Wrisley, Stephens, Mosley, Wojnowski, Duffy, \& Burkard, 2007).

The composite balance scores for all subjects as a whole, with or without holographic wristbands ( $85.9 \pm 2.9$ and $85.4 \pm 3.5$ ), are similar to those obtained by Wrisley (Wrisley, Stephens, Mosley, Wojnowski, Duffy, \& Burkard, 2007). In their study of 13 healthy university students ( 6 men and 7 women; age $24 \pm 4$ years), a value of $88.0 \pm 1.5$ was obtained in the session in which the test learning curve flattened out. In another study involving 112 students, a score of 70 points (95\% confidence level) was considered normal (Hamid, Hughes, \& Kinney, 1991; Shepard, Telian, \& Smith-Wheelock, 1990), rather lower than the present scores.

Although the standing position has been widely used for the assessment of subjects in this kind of study, the results obtained have their limitations when trying to extrapolate them to different settings and complex coordination tasks. Further, some authors suggest that simple standing is insufficiently taxing for use with healthy, active populations (DiStefano, Clark, \& Padua, 2009; Emery, 2003). Other authors indicate that SOT does not sufficiently challenge posture control in people with a highly developed sense of balance (Clark \& Iltis, 2008; Paloski, Wood, Feiveson, Black, Hwang, \& Reschke, 2006) or those who have well compensated balance problems (Roma, 2005).

Wearing a holographic wristband had no effect on any of the sensorial (visual, vestibular, somatosensorial) variables measured, as shown previously (Marban, Vega, Rodríguez, Pérez, \& Ramos, 2011; Brice, Jarosz, Ames, 2011; Pothier, 2012; Teruya, Matareli, Romano, 2013). The present sensorial results were similar to those reported by Wrisley (Wrisley, Stephens, Mosley, Wojnowski, Duffy, \& Burkard, 2007), whose study involved a similar sample of subjects (somatosensorial $0.97 \pm 0.01$ compared to $0.97 \pm 0.04$, visual $0.95 \pm 0.02$ compared to $0.95 \pm 0.02$, vestibular $0.77 \pm 0.08$ compared to $084 \pm 0.03$ ), confirming the present subjects to have good postural control. SOT results are, however, quite sensitive to changes in balance produced by age and disease (Cohen et al., 1996). For example, if the present results are compared to those of Tsang and Hui-Chan (2004) for healthy elderly, functionally independent people, those of the present, younger subjects are much better in terms of visual $(0.95 \pm 0.02$ compared to $0.68 \pm 0.19)$ and vestibular $(0.77 \pm 0.08$ compared to $0.51 \pm 0.20)$ scores.

Although the study of the influence of sex on balance was not the main aim of the present work, it should be noted that the overall mean showed significant sex- and wristband bandrelated differences at the statistical level (without reaching any threshold level of real importance). The overall mean reflects the mean combined scores for each of the sensorial conditions measured by the SOT. Its validity as a representative criterion of balance has been questioned (Ford-Smith, Wyman, Elswick, Fernandez, \& Newton, 1995) since it invests the results of conditions 1 and 2 with the same weight as 3-6, even though the former are less sensitive and reliable (Broglio, Ferrara, Sopiarz, \& Kelly, 2008; Dickin, 2010; Dickin \& Clark, 2007). The composite balance, which gives less weight to the results associated with 
Gonzalo, I.; Benito, P. J.; Delfa, J. M.; Miangolarra, M. A.; Rojo-Tirado, M. A. (2014). The effect of holographic wristbands on body balance. RICYDE. Revista internacional de ciencias del deporte, 38(10), 305-318. http://dx.doi.org/10.5232/ricyde2014.03802

conditions 1 and 2 more precisely reflects the balance of subjects (Nashner \& Peters, 1990); it was therefore chosen as the main reference variable in this study.

The small differences seen in the results for some variables associated with the wearing of a holographic wristband might be due to variations in the physical and psychological status of the subjects. Although all were given specific instructions regarding the taking of alcohol, medicines and exercise, subject tiredness from one day to the next may have affected the results of the tests, as reported in other studies (Dickin, 2010; Dickin \& Clark, 2007).

\section{Conclusion}

Certainly, holograms may be used in the generation of three dimensional images (Shiota, 2008) and in biosensors (Kabilan, Marshall, Sartain, Lee, Hussain, \& Yang, 2005; Sartain, Yang, \& Lowe, 2006), but there is no scientific evidence linking holograms with any improvement in any physical performance or capacity (Metha, 2005). In conclusion, along with the results of the present work, suggest that Power Balance ${ }^{\circledR}$ wristbands have no effect on balance or postural control in young, healthy, physically active people.

\section{Acknowledgements}

No public or private financing was used during this work. The authors confirm they have no conflicts of interest related to the topic of study.

\section{References}

Brice, S. R.; Jarosz, B. S.; Ames, R. A., (2011). The effect of close proximity holographic wristbands on human balance and limits of stability: A randomised, placebo-controlled trial. Journal of Bodywork and Movement Therapies, 15:298-303 http://dx.doi.org/10.1016/j.jbmt.2011.01.020

Broglio, S. P.; Ferrara, M. S.; Sopiarz, K., \& Kelly, M. S. (2008). Reliable change of the sensory organization test. Clinical Journal of Sport Medicine, 18(2), 148-154 http://dx.doi.org/10.1097/JSM.0b013e318164f42a

Clark, S., \& Iltis, P. W. (2008). Effects of dynamic head tilts on sensory organization test performance: a comparison between college-age athletes and nonathletes. Journal of Orthopaedic \& Sports Physical Therapy, 38(5), 262-268 http://dx.doi.org/10.2519/jospt.2008.2406

Cohen, H.; Heaton, L. G.; Congdon, S. L., \& Jenkins, H. A. (1996). Changes in sensory organization test scores with age. Age Ageing, 25(1), 39-44

Cumberworth, V. L.; Patel, N. N.; Rogers, W., \& Kenyon, G. S. (2007). The maturation of balance in children. The Journal of Laryngology \& Otorhinolaryngology, 121(5), 449-454 http://dx.doi.org/10.1017/S0022215106004051

Day, B. L.; Guerraz, M., \& Cole, J. (2002). Sensory interactions for human balance control revealed by galvanic vestibular stimulation. Advances in Experimental Medicine and Biology, 508, 129-137

Dickin, D. C. (2010). Obtaining reliable performance measures on the sensory organization test: altered testing sequences in young adults. Clinical Journal of Sport Medicine, 20(4), 278285 http://dx.doi.org/10.1097/JSM.0b013e3181e8f8b1

Dickin, D. C., \& Clark, S. (2007). Generalizability of the sensory organization test in college-aged males: obtaining a reliable performance measure. Clinical Journal of Sport Medicine, 17(2), 109-115 http://dx.doi.org/10.1097/JSM.0b013e31803bf647

DiStefano, L. J.; Clark, M. A., \& Padua, D. A. (2009). Evidence supporting balance training in healthy individuals: a systemic review. The Journal of Strength \& Conditioning Research, 23(9), 2718-2731 http://dx.doi.org/10.1519/JSC.0b013e3181c1f7c5 
Gonzalo, I.; Benito, P. J.; Delfa, J. M.; Miangolarra, M. A.; Rojo-Tirado, M. A. (2014). The effect of holographic wristbands on body balance. RICYDE. Revista internacional de ciencias del deporte, 38(10), 305-318. http://dx.doi.org/10.5232/ricyde2014.03802

Emery, C. A. (2003). Is there a clinical standing balance measurement appropriate for use in sports medicine? A review of the literature. Journal of Science and Medicine in Sport, 6(4), 492504

Ferber-Viart, C.; Ionescu, E.; Morlet, T.; Froehlich, P., \& Dubreuil, C. (2007). Balance in healthy individuals assessed with Equitest: maturation and normative data for children and young adults. International Journal of Pediatric Otorhinolaryngology, 71(7), 1041-1046 http://dx.doi.org/10.1016/j.ijporl.2007.03.012

Ford-Smith, C. D.; Wyman, J. F.; Elswick, R. K., Jr.; Fernandez, T., \& Newton, R. A. (1995). Testretest reliability of the sensory organization test in noninstitutionalized older adults. Archives of Physical Medicine and Rehabilitation, 76(1), 77-81

Furman, J. M. (1994). Posturography: uses and limitations. Baillieres Clinical Neurology, 3(3), 501513

Gabor, D.; Kock, W. E., \& Stroke, G. W. (1971). Holography. Science, 173(3991), 11-23 http://dx.doi.org/10.1126/science.173.3991.11

Galván, R. (2010, 29/04/2010). Las pulseras Power Balance, ¿timo o milagro? Retrieved 10/09/2010, from: http://www.elmundo.es/mundodinero/2010/04/28/economia/1272459006.html

Galvao, D. A.; Nosaka, K.; Taaffe, D. R.; Spry, N.; Kristjanson, L. J.; McGuigan, M. R., et al. (2006). Resistance training and reduction of treatment side effects in prostate cancer patients. Medicine \& Science in Sports \& Exercise, 38(12), 2045-2052 http://dx.doi.org/10.1249/01.mss.0000233803.48691.8b

Ganz, D. A.; Bao, Y.; Shekelle, P. G., \& Rubenstein, L. Z. (2007). Will my patient fall? Journal of American Medical Association, 297(1), 77-86 http://dx.doi.org/10.1001/jama.297.1.77

Gautier, G.; Thouvarecq, R., \& Vuillerme, N. (2008). Postural control and perceptive configuration: influence of expertise in gymnastics. Gait \& Posture, 28(1), 46-51 http://dx.doi.org/10.1016/j.gaitpost.2007.09.007

Geldhof, E.; Cardon, G.; De Bourdeaudhuij, I.; Danneels, L.; Coorevits, P.; Vanderstraeten, G., et al. (2006). Static and dynamic standing balance: test-retest reliability and reference values in 9 to 10 year old children. European Journal of Pediatrics, 165(11), 779-786 http://dx.doi.org/10.1007/s00431-006-0173-5

Goldie, P. A.; Bach, T. M., \& Evans, O. M. (1989). Force platform measures for evaluating postural control: reliability and validity. Archives of Physical Medicine and Rehabilitation, 70(7), 510517

Grindstaff, T. L.; Christiano, K. E.; Broos, A. M.; Straub, D. A.; Darr, N. S., \& Westphal, K. A. (2006). Assessment of a practice effect in serial sensory organization testing scores of healthy adults. Perceptual and Motor Skills, 102(2), 379-386

Hamid, M. A.; Hughes, G. B., \& Kinney, S. E. (1991). Specificity and sensitivity of dynamic posturography. A retrospective analysis. Acta Otolaryngol Supplement, 481, 596-600

Heitkamp, H. C.; Horstmann, T.; Mayer, F.; Weller, J., \& Dickhuth, H. H. (2001). Gain in strength and muscular balance after balance training. International Journal of Sports Medicine, 22(4), 285-290 http://dx.doi.org/10.1055/s-2001-13819

Horak, F. B. (1997). Clinical assessment of balance disorders. Gait \& Posture, 6, 76-84

Hrysomallis, C. (2007). Relationship between balance ability, training and sports injury risk. Sports Medicine, 37(6), 547-556

Hübscher, M.; Zech, A.; Pfeifer, K.; Hänsel, F.; Vogt, L., \& Banzer, W. (2010). Neuromuscular Training for Sports Injury Prevention: A Systematic Review. Medicine \& Science in Sports \& Exercise, 42(3), 413-421 http://dx.doi.org/10.1249/MSS.0b013e3181b88d37 
Gonzalo, I.; Benito, P. J.; Delfa, J. M.; Miangolarra, M. A.; Rojo-Tirado, M. A. (2014). The effect of holographic wristbands on body balance. RICYDE. Revista internacional de ciencias del deporte, 38(10), 305-318. http://dx.doi.org/10.5232/ricyde2014.03802

Kabilan, S.; Marshall, A. J.; Sartain, F. K.; Lee, M. C.; Hussain, A.; Yang, X., et al. (2005). Holographic glucose sensors. Biosensors and Bioelectronics, 20(8), 1602-1610 http://dx.doi.org/10.1016/j.bios.2004.07.005

Leitner, C.; Mair, P.; Paul, B.; Wick, F.; Mittermaier, C.; Sycha, T., et al. (2009). Reliability of posturographic measurements in the assessment of impaired sensorimotor function in chronic low back pain. Journal of Electromyography \& Kinesiology, 19(3), 380-390 http://dx.doi.org/10.1016/j.jelekin.2007.09.007

Lephart, S.; Riemann, B., \& Fu, F. (2000). Introduction to the Sensorimotor System. In S. Lephart \& F. Fu (Eds.), Proprioception and neuromuscular control in joint stability (pp. xvii-xxiv). Champaign, Illinois: Human Kinetics

Lord, S. R., \& Sturnieks, D. L. (2005). The physiology of falling: assessment and prevention strategies for older people. Journal of Science and Medicine in Sport, 8(1), 35-42

Mancini, M., \& Horak, F. B. (2010). The relevance of clinical balance assessment tools to differentiate balance deficits. European Journal of Physical and Rehabilitation Medicine, $46(2), 239-248$

Marban, R. M.; Vega, D. M.; Rodríguez, E. F.; Pérez, F. J. S., \& Ramos, O. R. (2011). Efecto del holograma Power Balance sobre el equilibrio, la flexibilidad, la fuerza y la velocidadcoordinación en estudiantes universitarios. Retos: nuevas tendencias en educación física, deporte y recreación, (19), 34-37

Marshall, A. J.; Blyth, J.; Davidson, C. A., \& Lowe, C. R. (2003). pH-sensitive holographic sensors. Analytical Chemistry, 75(17), 4423-4431

Martín Pascual, P. (1997). El libro de la holografía. Madrid: Alianza Editorial

McGuine, T. A.; Greene, J. J.; Best, T., \& Leverson, G. (2000). Balance as a predictor of ankle injuries in high school basketball players. Clinical Journal of Sport Medicine, 10(4), 239-244

Mckeon, P. O., \& Hertel, J. (2008a). Systematic review of postural control and lateral ankle instability, part I: can deficits be detected with instrumented testing. Journal of Athletic Training, 43(3), 293-304

Mckeon, P. O., \& Hertel, J. (2008b). Systematic review of postural control and lateral ankle instability, part II: is balance training clinically effective? Journal of Athletic Training, 43(3), 305-315

Metha, P. (2005). Medical Applications of Holography. Retrieved 11/09/2010, from: http://www.holokits.com/a-holography_medical_applications.htm

Mirka, A., \& Black, F. O. (1990). Clinical application of dynamic posturography for evaluating sensory integration and vestibular dysfunction. Neurologic Clinics, 8(2), 351-359

Muir, S. W.; Berg, K.; Chesworth, B.; Klar, N., \& Speechley, M. (2010). Quantifying the magnitude of risk for balance impairment on falls in community-dwelling older adults: a systematic review and meta-analysis. Journal of Clinical Epidemiology, 63(4), 389-406 http://dx.doi.org/10.1016/j.jclinepi.2009.06.010

Nashner, L. M. (1993). Computerized dynamic posturography. In G. Jacobson, C. Newman \& J. Kartush (Eds.), Handbook of balance function and testing (pp. 261-279). St. Louis: Mosby year Book

Nashner, L. M., \& Peters, J. F. (1990). Dynamic posturography in the diagnosis and management of dizziness and balance disorders. Neurologic Clinics, 8(2), 331-349

Nashner, L. M.; Shupert, C. L.; Horak, F. B., \& Black, F. O. (1989). Organization of posture controls: an analysis of sensory and mechanical constraints. Progress in Brain Research, 80, 411-418; discussion 395-417

NeuroCom $®$ International. (2001). EquiTest $®$ System Version 8.0 Data interpretation manual. Clackamas: NeuroCom $®$ International, Inc.

NeuroCom $®$ International. (2006). Smart Equitest ${ }^{\circledR}$ System Operator's Manual Version 8.2. Clackamas: NeuroCom $®$ International, Inc. 
Gonzalo, I.; Benito, P. J.; Delfa, J. M.; Miangolarra, M. A.; Rojo-Tirado, M. A. (2014). The effect of holographic wristbands on body balance. RICYDE. Revista internacional de ciencias del deporte, 38(10), 305-318. http://dx.doi.org/10.5232/ricyde2014.03802

Paloski, W. H.; Wood, S. J.; Feiveson, A. H.; Black, F. O.; Hwang, E. Y., \& Reschke, M. F. (2006). Destabilization of human balance control by static and dynamic head tilts. Gait \& Posture, 23(3), 315-323

http://dx.doi.org/10.1016/j.gaitpost.2005.04.009

Peinado, P. J. B., Molina, V. D., Montero, F. J. C., Lozano, A. B. P., Caro, C. M., Sánchez, M. A., \& Tejero, J. P. (2007). La revisión bibliográfica sistemática en fisiología del ejercicio: recomendaciones prácticas. RICYDE: Revista Internacional de Ciencias del Deporte, 3, 1-11 http://www.cafyd.com/REVISTA/art1n6a07.pdf

Pérez-Lanzac, C. (2010, 29/04/2010). Consumo advierte del engaño de las "pulseras milagro". Retrieved 08/08/2010, 2010, from:

http://www.elpais.com/solotexto/articulo.html?xref=20100429elpepisoc_4\&type=Tes\&anchor=elpe pisoc

Pothier, D. D., Thiel, G., Kho, S. G., Dillon, W. A., Sulway, S., \& Rutka, J. A. (2012). Efficacy of the Power Balance Silicone Wristband: a single-blind,randomized, triple placebo-controlled study. Journal of Otolaryngology Head and Neck Surgery, 41(3), 153-159

Roma, A. A. (2005). Use of the head shake-sensory organization test as an outcome measure in the rehabilitation of an individual with head movement provoked symptoms of imbalance. Journal of Geriatric Physical Therapy, 28(2), 58-63

Ross, S. E., \& Guskiewicz, K. M. (2004). Examination of static and dynamic postural stability in individuals with functionally stable and unstable ankles. Clinical Journal of Sport Medicine, $14(6), 332-338$

Sartain, F. K.; Yang, X., \& Lowe, C. R. (2006). Holographic lactate sensor. Analytical Chemistry, 78(16), 5664-5670 http://dx.doi.org/10.1021/ac060416g

Schuhfried, O.; Mittermaier, C.; Jovanovic, T.; Pieber, K., \& Paternostro-Sluga, T. (2005). Effects of whole-body vibration in patients with multiple sclerosis: a pilot study. Clinical Rehabilitation, 19(8), 834-842

Sell, T. C.; Tsai, Y. S.; Smoliga, J. M.; Myers, J. B., \& Lephart, S. M. (2007). Strength, flexibility, and balance characteristics of highly proficient golfers. The Journal of Strength \& Conditioning Research, 21(4), 1166-1171 http://dx.doi.org/10.1519/R-21826.1

Shepard, N. T.; Schultz, A.; Alexander, N. B.; Gu, M. J., \& Boismier, T. (1993). Postural control in young and elderly adults when stance is challenged: clinical versus laboratory measurements. The Annals of Otology, Rhinology and Laryngology, 102(7), 508-517

Shepard, N. T.; Telian, S. A., \& Smith-Wheelock, M. (1990). Habituation and balance retraining therapy. A retrospective review. Neurologic Clinics, 8(2), 459-475

Shiota, T. (2008). 3D echocardiography: The present and the future. Journal of Cardiology, 52(3), 169-185 http://dx.doi.org/10.1016/j.jjcc.2008.09.004

Sparkes, R., \& Behm, D. G. (2010). Training adaptations associated with an 8-week instability resistance training program with recreationally active individuals. The Journal of Strength \& Conditioning Research, 24(7), 1931-1941 http://dx.doi.org/10.1519/JSC.0b013e3181df7fe4

Sturnieks, D. L.; St George, R., \& Lord, S. R. (2008). Balance disorders in the elderly. Neurophysiology Clinics, 38(6), 467-478 http://dx.doi.org/10.1016/j.neucli.2008.09.001

Teruya, T. T., Matareli, B. M., Romano, F. S., (2013). The Effect of a Silicone Wristband in Dynamic Balance. Perceptual \& Motor Skills, 117:353-57 http://dx.doi.org/10.2466/06.26.PMS.117x20z6

Tsigilis, N., \& Theodosiou, A. (2008). The influence of multiple administration of a psychomotor test on performance and learning. The Journal of Strength \& Conditioning Research, 22(6), 1964-1968 http://dx.doi.org/10.1519/JSC.0b013e3181821b75 
Gonzalo, I.; Benito, P. J.; Delfa, J. M.; Miangolarra, M. A.; Rojo-Tirado, M. A. (2014). The effect of holographic wristbands on body balance. RICYDE. Revista internacional de ciencias del deporte, 38(10), 305-318. http://dx.doi.org/10.5232/ricyde2014.03802

Valovich McLeod, T. C. (2008). The effectiveness of balance training programs on reducing the incidence of ankle sprains in adolescent athletes. Journal of Sport Rehabilitation, 17(3), 316-323

Verdan, P. J., Marzilli, T. S., Barna, G. I., Roquemore, A. N., Fenter, B. A., Blujus, B. \& Gosselin, K.

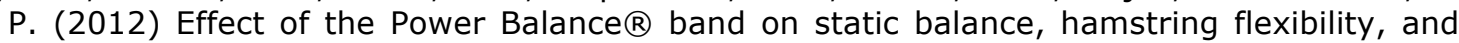
arm strength in adults. Journal of Strength and Conditioning Research, 26(8), 2113-2118 http://dx.doi.org/10.1519/JSC.0b013e31823a43ce

Visser, J. E.; Carpenter, M. G.; van der Kooij, H., \& Bloem, B. R. (2008). The clinical utility of posturography. Clinical Neurophysiology, 119(11), 2424-2436 http://dx.doi.org/10.1016/j.clinph.2008.07.220

Wikstrom, E. A.; Fournier, K. A., \& McKeon, P. O. (2010). Postural control differs between those with and without chronic ankle instability. Gait \& Posture, 32(1), 82-86 http://dx.doi.org/10.1016/j.gaitpost.2010.03.015

World Medical Association. (2004, 17/05/05). Declaración de Helsinki para la investigación con seres humanos. Retrieved 24/09/04, 2004, from: http://www.wma.net/s/policy/b3.htm

Wrisley, D. M.; Stephens, M. J.; Mosley, S.; Wojnowski, A.; Duffy, J., \& Burkard, R. (2007). Learning effects of repetitive administrations of the sensory organization test in healthy young adults. Archives of Physical Medicine and Rehabilitation, 88(8), 1049-1054 http://dx.doi.org/10.1016/j.apmr.2007.05.003 